\title{
Upaya Peningkatan Kemampuan Belajar Siswa Kelas VII Dalam Pendidikan Berkarakter Dengan Pendekatan Metode Studi Pustaka
}

\author{
Malum Manik, S.Pd.I \\ SMP Negeri 2 Sampoiniet
}

\begin{abstract}
Abstrak
PTK ini mengkaji tentang peran konsep pendidikan karakter (Analisis Pemikiran AlGhazali). Dengan tujuan untuk mengetahui konsep pendidikan karakter berbasis psikologi Islam menurut Azyumardi Azra dan Al-Ghazali. Kajian ini dilakukan dengan menggunakan metode studi pustaka (Library Research). Hasil dari studi ini menunjukkan bahwa Pendidikan karakter merupakan pendidikan yang berorientasi pada tingkah laku dan akhlak terpuji serta tata krama yang berisikan kebiasaan sopan santun yang disepakati dalam lingkungan pergaulan antar manusia. tujuan pendidikan karakter yaitu meningkatkan keimanan, pemahaman, penghayatan dan pengalaman seseorang terhadap ajaran islam sehingga menjadi orang muslim yang bertakwa kepada Allah SWT serta berakhlak mulia dalam kehidupan pribadi, bermasyarakat, berbangsa dan bernegara. Psikologi Islam adalah suatu ilmu yang mempelajari gejala kejiwaan manusia yang normal, dewasa dan beradab, dan didasarkan pada Al-Quran sebagai sumber hukum Islam dan hakekatnya berhubungan dengan aspek-aspek dan perilaku kejiwaan manusia, agar secara sadar ia dapat membentuk kualitas diri yang lebih sempurna dan mendapatkan kebahagiaan hidup di dunia dan akhirat. Kemudian tumbuhkan tindakan, sikap, pandangan, pendirian, keyakinan dan kesadaran serta kepercayaan untuk berbuat sesuatu yang bertanggung jawab akhirnya terbentuklah kata hati (kerohanian yang luhur) pada anak pada masa dewasanya. Disamping itu, pendidikan karakter dapat dilakukan dengan membina nilai-nilai kemasyarakatan, kesusilaan dan keagamaan yang disatupadukan, sehingga terwujud sikap, mental, akhlak dan kepribadian yang sesuai dengan ajaran agama Islam.
\end{abstract}

\section{Kata kunci: "Komparasi Konsep Pendidikan Karakter Pemikiran Azyumardi Azra dan Al-Ghazali”.}

\section{PENDAHULUAN}

Guru memiliki peranan yang sangat penting dalam menentukan kuantitas dan kualitas pengajaran yang dilaksanakan. Oleh sebab itu, guru harus memikirkan dan membuat perencanaan secara seksama dalam meningkatkan kesempatan belajar bagi siswanya dan memperbaiki kualitas mengajarnya.

Hal ini menuntut perubahan-perubahan dalam mengorganisasikan kelas, penggunaan metode mengajar, strategi belajar mengajar, maupun sikap dan karakteristik guru dalam mengelola proses belajar mengajar. Guru berperan sebagai pengelola proses belajar-mengajar, bertindak sebagai fasilitor yang berusaha mencipatakan kondisi belajar mengajar yang efektif, sehingga memungkinkan proses belajar mengajar, mengembangkan bahan pelajaran dengan baik, dan meningkatkan kemampuan siswa untuk menyimak pelajaran dan menguasai tujuan-tujuan pendidikan yang harus mereka capai. Untuk memenuhi hal tersebut di atas, guru dituntut mampu mengelola proses belajar mengajar yang memberikan rangsangan kepada siswa, sehingga ia mau belajar karena siswalah subyek utama dalam belajar. 
Kegiatan belajar bersama dapat membantu memacu belajar aktif. Kegiatan belajar dan mengajar di kelas memang dapat menstimulasi belajar aktif. Namun kemampuan untuk mengajar melalui kegiatan kerjasana kelompok kecil akan memungkinkan untuk menggalakkan kegiatan belajar aktif dengan cara khusus. Apa yang didiskusikan siswa dengan teman-temannya dan apa yang diajarkan siswa kepada teman-temannya memungkinkan mereka untuk memperoleh pemahaman dan penguasaan materi pelajaran.

Pembelajaran Agama Islam tidak lagi mengutamakan pada penyerapan melalui pencapaian informasi, tetapi lebih mengutamakan pada pengembangan kemampuan dan pemrosesan informasi. Untuk itu aktifitas peserta didik perlu ditingkatkan melalui latihan-latihan atau tugas dengan bekerja dalam kelompok kecil dan menjelaskan ideide kepada orang lain. (Hartoyo, 2000:24).

Berdasarkan uraian tersebut diatas maka peneliti ingin mencoba melakukan penelitian dengan judul "Upaya peningkatan kemampuan belajar siswa kelas VII dalam pendidikan berkarakter dengan pendekatan metode studi pustaka" Pada Siswa SMP Negeri 2 Sampoiniet Kecamatan Sampoiniet Kabupaten Aceh Jaya Tahun Pelajaran $2020 / 2021$.

\section{Tujuan Penelitian}

Sesuai dengan permasalahan di atas, penelitian ini bertujuan untuk :

1. Ingin mengetahui peningkatan prestasi belajar siswa setelah diterapkannya metode pemberian tugas belajar dan resitasi.

2. Ingin mengetahui pengaruh motivasi belajar siswa setelah diterapkan metode pemberian tugas belajar dan resitasi.

\section{KAJIAN PUSTAKA}

\section{Pengajaran metode studi pustaka dan resitasi}

Studi pustaka dan resitasi ialah suatu cara mengajar di mana seorang guru memberikan tugas-tugas tertentu kepada peserta didik, sedangkan hasil tersebut di periksa oleh guru dan peserta didik mempertanggung jawabkannya. Pertanggungan jawab itu dapat dilaksanakan dengan cara :

- Dengan menjawab test yang diberikan oleh guru.

- Dengan menyampaikan ke muka berupa lisan

- Dengan cara tertulis.

Dalam metode ini kita menemukan tiga istilah penting yaitu tugas, belajar, resitasi.

Prinsip yang mendasari metode ini ada dalam AI-Quran. Tuhan memberikan suatu tugas yang berat terhadap Nabi Muhammad sebelum dia melaksanakan tugas keRasulannya. Tugas yang diintruksikan itu ialah berupa sifat-sifat kepemimpinan yang harus dimiliki.

Firman Allah S.W.T

Hai orang yang berselubung, bangunlah dan pertakutilah kaummu, hendak besarkan Tuhan-mu. Dan bersihkanlah pakaianmu! Tinggallah pekerjaan-pekerjaan yang mendatangkan siksaan. Janganlah engkau memberi kepada orang lain lantaran hendak meminta lebih banyak. Sabar dan uletlah menurut perintah Tuhan. (Q.S. Al Mudatatsir: 1-7).

\section{Pase-pase Resitasi}

Dengan metode Resitasi terdapat 3 fase yaitu : 
1. Guru memberikan tugas:

2. Tugas yang diberikan oleh guru harus disesuaikan dengan kemampuan peserta didik. Dalam pelaksanaan tugas itu kemungkinan peserta didik akan menjawab dan penyelesaikan suatu bentuk hitungan dan ada pula berbentuk sesuatu yang harus diselesaikan, ada pula berbentuk sesuatu yang baik dari berbagai aspek.

3. Murid melaksanakan tugas (belajar) cara murid belajar akan terlaksana dengan balk apabila dia belajar sesuai dengan petunjuk yang diberikan guru dan sesuai dengan tujuan yang hendak dicapai.

4. Murid mempertanggung jawabkan hasil, pekerjaannya (resitasinya). Resitasi itu juga akan wajar apabila sesuai dengan tujuan pemberian tugas.

\section{METODOLOGI PENELITIAN}

\section{Tempat dan Waktu Penelitian}

Tempat penelitian adalah tempat yang digunakan dalam melakukan penelitian untuk memperoleh data yang diinginkan. Penelitian ini bertempat di SMP Negeri 2 Sampoiniet Kecamatan Sampoiniet Kabupaten Aceh Jaya Tahun Pelajaran 2020/2021. Waktu penelitian adalah waktu berlangsungnya penelitian atau saat penelitian ini dilangsungkan. Penelitian ini dilaksanakan pada Minggu I bulan Oktober semester ganjil 2020/2021.

\section{Subyek Penelitian}

Subyek penelitian adalah siswa-siswi Kelas VII SMP Negeri 2 Sampoiniet Kecamatan Sampoiniet Kabupaten Aceh Jaya Tahun Pelajaran 2020/2021.

\section{Rancangan Penelitian}

Penelitian ini menggunakan Penelitian Tindakan Kelas (PTK). Menurut Tim Pelatih Proyek PGSM, PTK adalah suatu bentuk kajian yang bersifat reflektif oleh pelaku tindakan yang dilakukan untuk meningkatkan kemantapan rasional dari tindakan mereka dalam melaksanakan tugas, memperdalam pemahaman terhadap tindakantindakan yang dilakukan itu, serta memperbaiki kondisi dimana praktek pembelajaran tersebut dilakukan (dalam Mukhlis, 2000: 3).

\section{Instrumen Penelitian}

Instrumen yang digunakan dalam penelitian ini terdiri dari Silabus, Rencana Pelaksanaan Pembelajaran (RPP), Lembar Kegiatan Siswa, Lembar Observasi Kegiatan Belajar Mengajar, Tes formatif.

\section{Metode Pengumpulan Data}

Data-data yang diperlukan dalam penelitian ini diperoleh melalui observasi pengolahan metode pemberian tugas belajar dan resitasi, observasi aktivitas siswa dan guru, dan tes formatif.

\section{Teknik Analisis Data}

Untuk mengetahui keefektivan suatu metode dalam kegiatan pembelajaran perlu diadakan analisa data. Pada penelitian ini menggunakan teknik analisis deskriptif kualitatif, yaitu suatu metode penelitian yang bersifat menggambarkan kenyataan atau fakta sesuai dengan data yang diperoleh dengan tujuan untuk mengetahui prestasi 
belajar yang dicapai siswa juga untuk memperoleh respon siswa terhadap kegiata pembelajaran serta aktivitas siswa selama proses pembelajaran.

Untuk mengalisis tingkat keberhasilan atau persentase keberhasilan siswa setelah proses belajar mengajar setiap putarannya dilakukan dengan cara memberikan evaluasi berupa soal tes tertulis pada setiap akhir putaran.

Analisis ini dihitung dengan menggunakan statistik sederhana yaitu:

1. Untuk menilai ulangan suatu tes formatif. Peneliti melakukan penjumlahan nilai yang diperoleh siswa, yang selanjutnya dibagi dengan jumlah siswa yang ada di kelas tersebut sehingga diperoleh rata-rata tes formatif dapat dirumuskan:

$\bar{X}=\frac{\sum X}{\sum N}$
Dengan $\quad: \bar{X} \quad=$ Nilai rata-rata
$\Sigma \mathrm{X}=$ Jumlah semua nilai siswa
$\Sigma \mathrm{N}=$ Jumlah siswa

2. Untuk ketuntasan belajar, ada dua kategori ketuntasan belajar yaitu secara perorangan dan secara klasikal. Berdasarkan petunjuk pelaksanaan belajar mengajar kurikulum 1994 (Depdikbud, 1994), yaitu seorang siswa telah tuntas belajar bila telah mencapai skor $60 \%$ atau nilai 6.0, dan kelas disebut tuntas belajar bila di kelas tersebut terdapat $85 \%$ yang telah mencapai daya serap lebih dari sama dengan $60 \%$. Untuk menghitung persentase ketuntasan belajar digunakan rumus sebagai berikut :

$$
P=\frac{\sum \text { Siswa.yang.tuntas.belajar }}{\sum \text { Siswa }} \times 100 \%
$$

\section{HASIL PENELITIAN DAN PEMBAHASAN}

Penelitian tindakan kelas ini dilaksanakan dalam 3 minggu dengan 3 siklus. prosedur pelaksanaan dalam setiap siklus adalah perencanaan, pelaksanaan, pengamatan, dan refleksi. Rincian prosedur pelaksanaan penelitian pada siklus 1 dipaparkan secara lengkap dan rinci, sedang untuk siklus selanjutnya prosedur pelaksanaan hampir sama dengan siklus yang pertama. Dengan demikian pembahasannya difokuskan pada hasil observasi dan analisa refleksi.

\section{Proses Pembelajaran}

Kondisi pembelajaran sebelum dilakukan dan sesudah dilakukan tindakan dengan menggunakan media sebagai alat bantu terjadi peningkatan terlihat dari semangat siswa dalam mengikuti pelajaran. Berbagai bentuk gambar yang membuat siswa bertanya dalam kegiatan belajar yang akan mengalami saat itu. Guru menjelaskan dengan baik sehingga siswa dapat menunjukkan gambar yang sesuai dengan materi pembelajaran.

\section{Deskripsi Pelaksanaan Siklus I}

Berdasarkan kondisi yang di lapangan bahwa siswa kelas VII SMP Negeri 2 Sampoiniet Kecamatan Sampoiniet Kabupaten Aceh Jaya mengalami hasil nilai yang diperoleh siswa kurang memuaskan belum sepenuhnya dapat menguasai materi pembelajaran PAI, dimana banyak siswa kelihatan tidak aktif dan kreatif dalam menerima pelajaran tersebut. Maka pada penelitian ini peneliti berupaya untuk memperbaiki kondisi pembelajaran tersebut dengan berupaya menerapkan sistem pembelajaran yang dikenal dengan PAIKEM (pembelajaran aktif, Inovatif, kreatif, 
efektif dan menyenangkan), disini peneliti juga mengupayakan dengan mengoptimalkan penggunaan metode, media pembelajaran yang sesuai dan dekat dengan lingkungan anak serta menciptakan suasana pembelajaran yang menyenangkan. Sebagai indikator bagi tercapainya suatu tujuan pembelajaran peneliti menetapkan standar ketuntasan materi yaitu nilai 7,0 atau $70 \%$ baik secara individu maupun secara klasikal.

Berikut ini peneliti sampaikan hasil belajar Mata Pelajaran Pendidikan Agama Islam yang masing-masing terdiri dari 2 siklus pogram perbaikan yang telah peneliti lakukan dari masing - masing siklus.

\section{Siklus Pertama ( Tanggal 09 Oktober 2021 )}

Dalam pelaksanaan siklus pertama peneliti menguraikan yaitu sebagai berikut :

\section{a. Perencanaan}

Perencanaan diawali dengan pembuatan rencana pembelajaran atau silabus yang dilengkapi dengan petunjuk demonstrasi alat peraga yang dilaksanakan oleh siswa dengan petunjuk yang disediakan, model, lembar pengamatan atau observasi yang dikerjakan secara kelompok, LKS (lembar kerja siswa), kuisioner yang diisi oleh siswa. Pelaksanaan pembelajaran menggunakan pendekatan diskusi kelompok.

\section{b. Pelaksanaan}

Peneliti mengimplementasikan rencana yang telah direncanakan sesuai dengan prosedur yang telah dibuat, serta peneliti mengawali dengan memberikan contoh manfaat mempelajari Iman Kepada Allah swt. dan al-asma al-husna dalam kehidupan nyata atau secara kontekstual dan pada akhir pelajaran siswa diberikan Apersepsi, Pre test, memberikan penjelasan serta memberikan acuan terhadap pembelajaran untuk hari ini dilanjutkan pembentukan kelompok diskusi yang tediri dari empat orang untuk setiap kelompok, menyelesaikan tugasnya masing dan melaporkan hasil kerjanya masing - masing kedepan kelas, ini dilakukan setiap kali pertemuan pada akhir pembelajaran di berikan evaluasi dalam RPP, dari analisis terhadap hasil belajar yang belum dicapai oleh siswa, data siswa yang memperoleh nilai $70 \mathrm{ke}$ atas dari target KKM 70 berjumlah 13 orang dari keseluruhan 29 orang, maka jumlah siswa-siswi yang mengalami ketidaktuntasan atau belum memperoleh nilai menurut tuntutan KKM berjumlah 16 orang.

Tabel Hasil belajar siswa Prasiklus

\begin{tabular}{|c|c|c|c|c|}
\hline \multirow{3}{*}{ Prasiklus } & \multicolumn{2}{|c|}{ Peroleh hasil belajar (KKM 70) } & \multicolumn{2}{c|}{ Ketuntasan (\%) } \\
\cline { 2 - 5 } & Nilai 70 ke atas & Nilai 70 ke bawah & Tuntas & Tidak tuntas \\
\cline { 2 - 5 } & 13 Orang & 16 Orang & $45 \%$ & $55 \%$ \\
\hline
\end{tabular}

\section{c. Observasi}

Observasi yang dilakukan pada siklus I ini antara lain adalah aktivitas siswa saat PBM berlangsung dan pelaksanaan PBM diselenggarakan oleh guru. Hasil observasi guru terhadap aktivitas pada saat proses belajar mengajar berlangsung dengan menggunakan lembar observasi aktivitas siswa yaitu $65 \%$. Hal ini menunjukkan bahwa aktivitas siswa tergolong katagori baik dari yang diharapkan oleh peneliti.

Table Data aktivitas siswa dalam PBM prasiklus

\begin{tabular}{|c|l|c|c|}
\hline No & \multicolumn{1}{|c|}{ Aspek yang dinilai } & Jumlah siswa Aktif & Perentase (\%) \\
\hline 1 & Memperhatikan penjelasan Guru & 17 & $59 \%$ \\
\hline 2 & Menjawab pertanyaan guru & 9 & $31 \%$ \\
\hline 3 & $\begin{array}{l}\text { Memperbaiki jawaban yang } \\
\text { salah }\end{array}$ & 22 & $76 \%$ \\
\hline 4 & Ikut menulis materi pelajaran & 22 & $76 \%$ \\
\hline
\end{tabular}




\begin{tabular}{|c|l|l|l|}
\hline 5 & Ikut membaca materi pelajaran & 24 & $83 \%$ \\
\hline \multicolumn{3}{|c|}{ Rata-rata aktivitas siswa (\%) } & $\mathbf{6 5 \%}$ \\
\hline
\end{tabular}

Selanjutnya hasil observasi terhadap kemampuan guru dalam pelaksanaan belajar mengajar dapat dilihat pada table dibawah ini :

Tabel Data kemampuan PBM guru prasiklus

\begin{tabular}{|c|l|c|}
\hline No & \multicolumn{1}{|c|}{ Aspek yang diamati } & Katagori \\
\hline 1 & Guru menyampaikan tujuan pembelajaran & Cukup \\
\hline 2 & Guru memotivasi siswa untuk mengikuti pelajaran dengan baik & Cukup \\
\hline 3 & Guru mengelola PBM dengan menggunakan media belajar & Kurang \\
\hline 4 & Guru membimbing siswa menulis secara individu & Cukup \\
\hline 5 & Guru membimbing siswa membaca dengan benar & Cukup \\
\hline 6 & Guru memberikan penjelasan akhir dan penguatan & Cukup \\
\hline 7 & Guru melakukan penilaian & Baik \\
\hline \multicolumn{2}{|c|}{ Rata-rata Katagori } & Cukup \\
\hline $\begin{array}{l}\text { Catatan : Dari data yang diperoleh rata-rata, kemampuan guru dalam } \\
\text { melakukam PBM adalah termasuk dari katagori Cukup dan perlu perbaikan } \\
\text { dalam PBM yaitu : pada saat menyampaikan tujuan pembelajaran, membimbing } \\
\text { siswa dalam menulis, membaca serta pengelolaan PBM dengan semaksimal } \\
\text { mungkin. }\end{array}$ \\
\hline
\end{tabular}

d. Refleksi

Setelah siklus I selesai dilakukan beserta penilaian terhadap hasil belajar siswa aktivitas siswa dam kemampuan guru dalam dilaksanakan PBM, guru peneliti bersama dengan guru kaloborasi membuat pertemuan untuk membahas tentang tindakan dan mendiskusikan dan menganalisa hasil pre test, post tes dan aktifitas siswa dalam proses pembelajaran yang dilakukan oleh guru. Peneliti dan kelompok untuk menemukan permasalahan dan menentukan permasalahan dan menentukan langkah perbaikan selanjutnya akan terjadi hal-hal unik yang muncul pada saat perbaikan pembelajaran yaitu :

- Terjadinya peningkatan prestasi siswa dengan pesat

- Hampir semua siswa berani mengajukan pertanyaan

- Terlihat hampir semua siswa sudah percaya diri dalam melakukan sesuatu tugas yang diberikan guru.

- Kondisi belajar siswa sangat menyenangkan.

- Kondisi siswa sudah terlihat mampu dalam memberikan tanggapannya masingmasing

- Siswa sudah terlihat tidak takut lagi dalam mengkritik temannya jika tanggapan temannya dianggap kurang bermanfaat.

\section{e. Evaluasi}

Setelah dilakukan kegiatan kerja kelompok untuk mengukur keberhasilan secara klasikal diberikan tugas sebanyak sepuluh soal sesuai dengan materi yang telah di pelajari. 


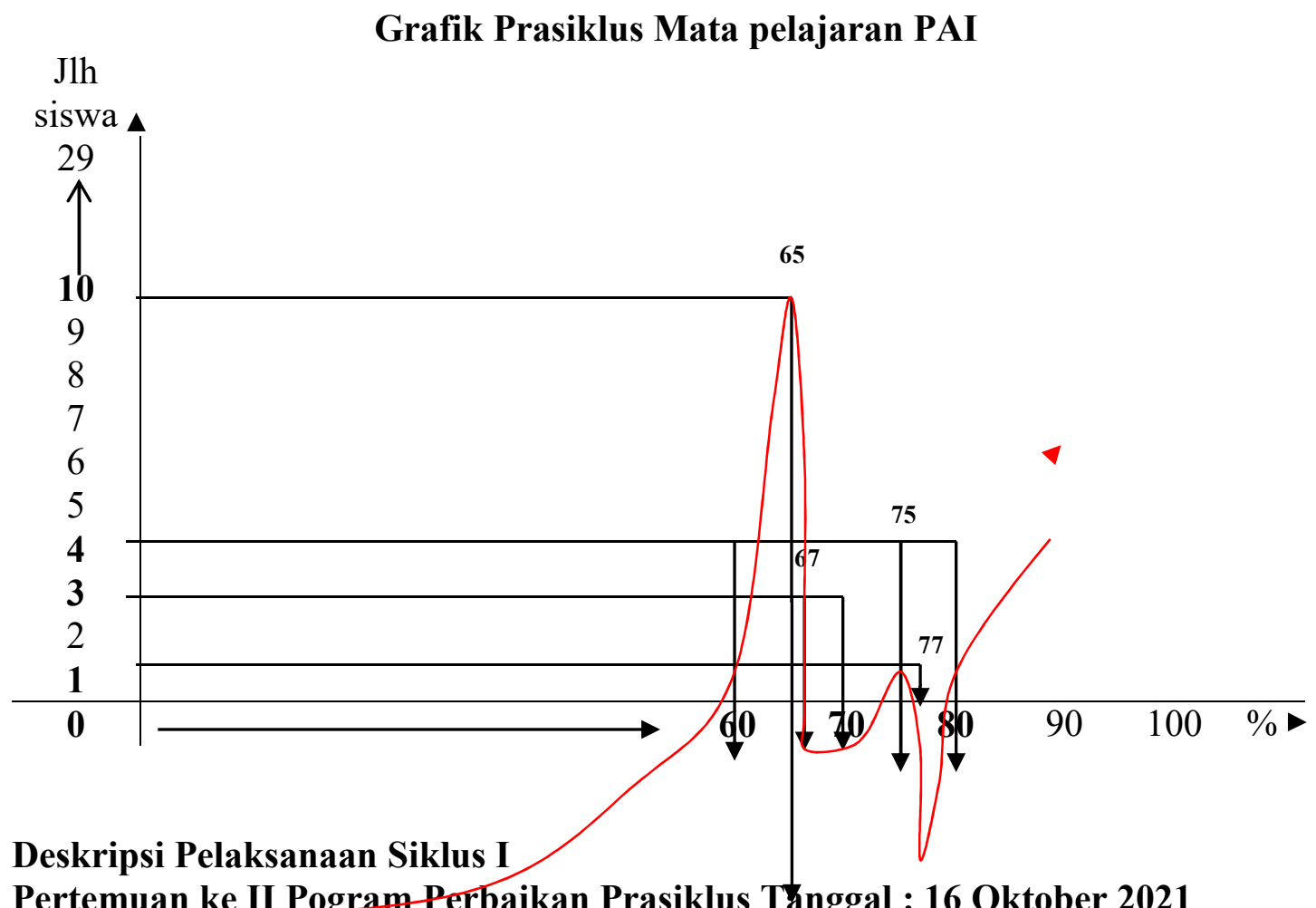

\section{Pertemuan ke II PogramPerbaikan Prasiklus Tănggal : 16 Oktober 2021}

Setelah dilakukan tahap pertama sebagai pogram perbaikan, pada tahap ke dua ini merupakan pogram perbaikan pada siklus kedua dengan uraian sebagai berikut :

\section{a. Perencanaan}

Membuat rencana perbaikan pembelajaran untuk mengatasi penyebab masalah yang timbul dari hasil refleksi siklus 1 yaitu :

a. Membimbing kelompok yang masih pasif.

b. Mendekati anggota kelompok yang masih suka nyontek dan tukar menukar jawaban dengan kelompoknya.

c. Mendampingi anak-anak dalam bekerja kelompok untuk dapat menuntaskan soal pada akhir pembelajaran.

\section{b. Pelaksanaan}

Pelaksanaan pembelajaran pada siklus II dilaksanakan sesuai perencanaan dengan alokasi waktu 2 × 35 menit pelajaran, perbaikan PBM yang harus dilakukan yaitu sesuai dengan hasil observasi guru, kaloborasi yaitu menyampaikan tujuan pembelajaran yang disampaikan belum cukup jelas. Membimbing siswa dengan cara mendekati tempat duduk siswa secara individu saat siswa mengamati gambar.

Pembentukan kelompok siswa dan menjelaskan kembali Pada menit-menit pertama masuk setelah berdoa dan absensi kemudian memberikan motivasi dengan cara bernyanyi salah satu lagu riang yang mereka sukai, kemudian dilanjutkan dengan memberikan Observasi dan sedikit penjelasan tentang materi pembelajaran serta apa saja yang dilakukan dalam pembelajaran ini. Melanjutkan pembelajaran dengan kerja kelompok pada akhir pertemuan diberikan tes tulisan. Dari pembelajaran yang dilakukan memperoleh hasil sebagai berikut :

Tabel Hasil belajar siswa siklus I

\begin{tabular}{|c|c|c|c|c|}
\hline \multirow{3}{*}{ Siklus I } & \multicolumn{2}{|c|}{ Peroleh hasil belajar (KKM 70) } & \multicolumn{2}{c|}{ Ketuntasan (\%) } \\
\cline { 2 - 5 } & Nilai 70 ke atas & Nilai 70 ke bawah & Tuntas & Tidak tuntas \\
\cline { 2 - 5 } & 27 Orang & 2 Orang & $93 \%$ & $7 \%$ \\
\hline
\end{tabular}




\section{c. Observasi}

Hasil observasi, keaktifan siswa dan kemampuan guru kolabor dan supervisor lebih cermat dan teliti dalam mengambil data untuk mengetahui aktifitas siswa baik dalam kerja kelompok maupun individual.

Table Data aktivitas siswa dalam PBM siklus I

\begin{tabular}{|c|l|c|c|}
\hline No & \multicolumn{1}{|c|}{ Aspek yang dinilai } & Jumlah siswa Aktif & Perentase (\%) \\
\hline 1 & Memperhatikan penjelasan Guru & 25 & $86 \%$ \\
\hline 2 & Menjawab pertanyaan guru & 19 & $65 \%$ \\
\hline 3 & Memperbaiki jawaban yang salah & 26 & $90 \%$ \\
\hline 4 & Ikut menulis materi pelajaran & 29 & $100 \%$ \\
\hline 5 & Ikut membaca materi pelajaran & 29 & $100 \%$ \\
\hline \multicolumn{3}{|c|}{ Rata-rata aktivitas siswa (\%) } & $\mathbf{8 8} \%$ \\
\hline
\end{tabular}

Data hasil observasi terhadap aktivitas siswa terjadi peningkatan $65 \%$ pada prasiklus menjadi $88 \%$ di siklus I. Kenaikan persentase aktivitas siswa disebabkan adanya tindakan guru yang terus membimbing siswa secara individu ikut mempengaruhi kenaikan aktivitas tersebut. Dari data yang diperoleh masih ada siswa yang belum aktif telah dilakukan tindak lanjut memperpendekatan individu berulangulang.

Selanjutnya hasil observasi yang dilakukan guru terhadap PBM yang dilakukan oleh guru juga terjadi peningkatan karena dapat memperbaiki kekurangan dalam kegiatan prasiklus. Observasi juga dilakukan oleh guru yang sama di siklus I, untuk lebih jelas dapat dilihat pada table dibawah ini :

Tabel Data kemampuan PBM guru siklus I

\begin{tabular}{|c|l|c|}
\hline No & \multicolumn{1}{|c|}{ Aspek yang diamati } & Katagori \\
\hline 1 & Guru menyampaikan tujuan pembelajaran & Baik \\
\hline 2 & Guru memotivasi siswa untuk mengikuti pelajaran dengan baik & Cukup \\
\hline 3 & Guru mengelola PBM dengan menggunakan media belajar & Baik \\
\hline 4 & Guru membimbing siswa menulis secara individu & Baik \\
\hline 5 & Guru membimbing siswa membaca dengan benar & Baik \\
\hline 6 & Guru memberikan penjelasan akhir dan penguatan & Baik \\
\hline 7 & Guru melakukan penilaian & Baik \\
\hline \multicolumn{2}{|c|}{ Rata-rata Katagori } & Baik \\
\hline $\begin{array}{l}\text { Catatan : Dari data yang diperoleh rata-rata, kemampuan guru dalam } \\
\text { melakukam PBM adalah termasuk dari katagori Baik, ini disebabkan karena } \\
\text { telah dilakukan perbaikan terhadap proses PBM pada siklus I. }\end{array}$ \\
\hline
\end{tabular}

\section{d. Refleksi}

Kolabor antara guru peneliti serta bersama dengan teman sejawat menganalisis semua kejadian yang sempat di catat pada lembaran pengamatan begitu juga dari peneliti sendiri terutama pada lembaran evaluasi akhir. Dari semua data yang ada setelah di analisis menunjukan hasil evaluasi yang meningkat dengan rata-rata tujuh, namun disini pada saat pembelajaran tidak semua anak dapat didekati untuk diberikan perhatian dan motivasi. Sehingga masih ada juga anak-anak yang hanya duduk saja dalam kelompok mengharapkan pada temannya untuk diselesaikan. Selanjutnya dirasa masih kurang aktif dalam menanggapi dari setiap laporan kelompok lain yang disampaikan didepan kelas.

\section{e. Evaluasi}

Untuk mengukur keberhasilan siswa setelah diadakan perbaikan, guru mengadakan evaluasi dan setelah melaksanakan perbaikan pembelajaran maka untuk 
mengukur keberhasilan itu siswa secara individu dan klasikal maka diadakan evaluasi kembali.

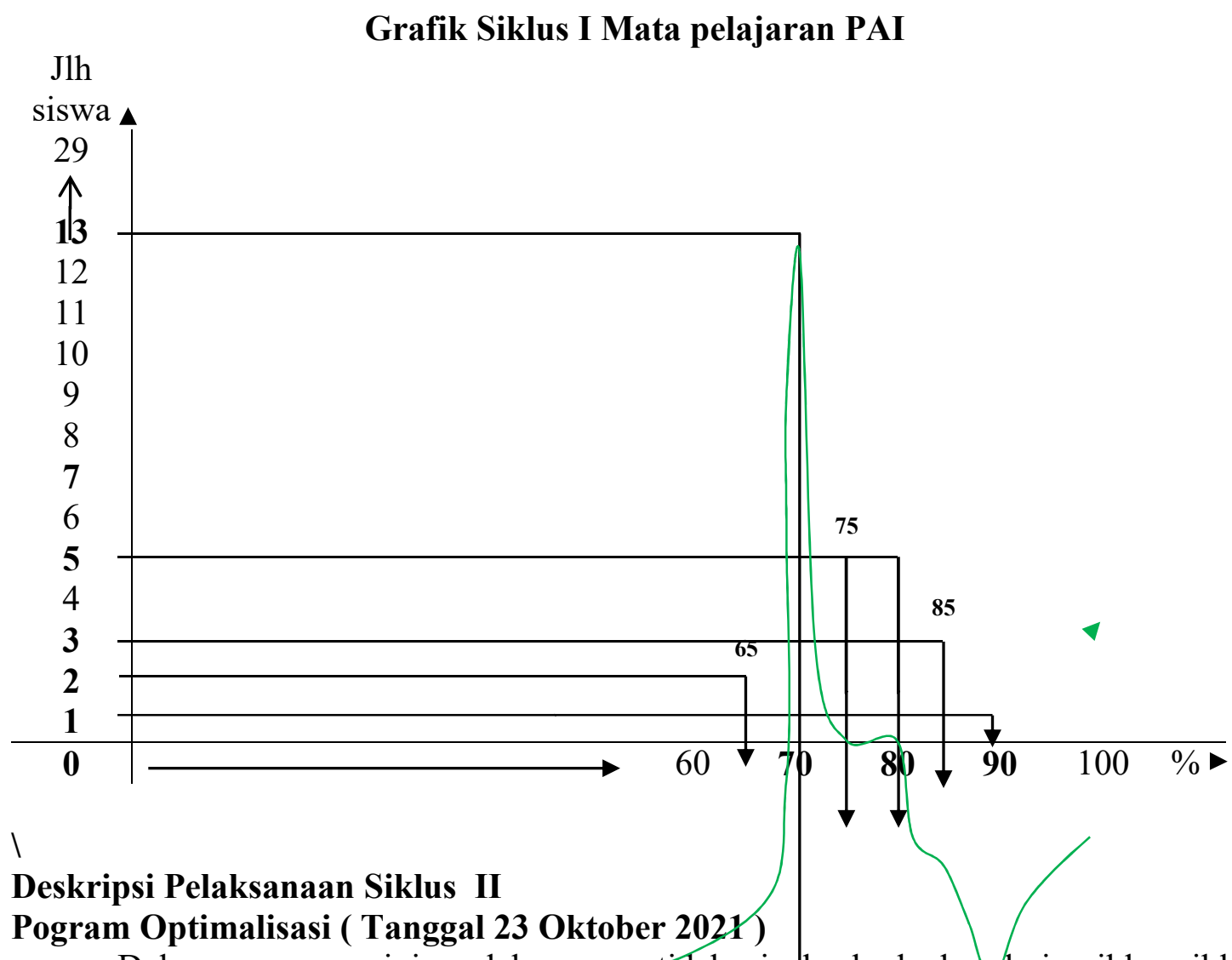

Dalam pogram ini pelaksanaan tidak jauh berbeda dari siklus-siklus sebelumnya, dimana dalam pertemuan ini mengoptimalkan semua hal-hal yang telah dilakukan dan pogram perbaikan yang dilakukan dalam siklus ini. Untuk rincian kegiatan dalam siklus ini yaitu sebagai berikut :

\section{a. Perencanaan}

Membuat rencana pembelajaran untuk mengatasi temuan kendala pembelajaran pada siklus I dan mengoptimalkan program perbaikan pada siklus II yaitu banyaknya waktu yang diperlukan serta masih sulitnya siswa bersosialisasi sesama teman.

\section{b. Pelaksanaan}

Pembentukan kelompok, serta mengadakan pengamatan dan metode yang bervariasi dan mengoptimalkan bimbingan perkelompok yang benar-benar pasif, maka selanjutnya mewakili setiap kelompok untuk melaporkan hasilanya kedepan kelas selesai melaporkan hasil kerja kelompok tersebut dipajangkan pada tempat yang telah di sediakan.

Tabel Hasil belajar siswa siklus II

\begin{tabular}{|c|c|c|c|c|}
\hline \multirow{3}{*}{ Siklus II } & \multicolumn{2}{|c|}{ Peroleh hasil belajar (KKM 70) } & \multicolumn{2}{c|}{ Ketuntasan (\%) } \\
\cline { 2 - 5 } & Nilai 70 ke atas & Nilai 70 ke bawah & Tuntas & Tidak tuntas \\
\cline { 2 - 5 } & 29 Orang & 0 Orang & $100 \%$ & $0 \%$ \\
\hline
\end{tabular}

\section{c. Observasi}

Kolabor bersama guru peneliti memberikan angket siswa, wawancara siswa, wawancara terhadap guru, menganalisa hasil test setelah selesai tindakan, juga disini juga dibantu oleh teman sejawat untuk mengamati serta merekam semua kejadian yang 
terjadi dalam kegiatan pembelajaran, disini melihat anak-anak dengan leluasa dalam kreatifitasnya dan cukup aktif dalam kegiatan kelompoknya. Dalam hal ini tentunya juga masih ada anak yang merasa malu dalam memberikan tanggapan mengenai laporan temannya yang dibacakan di depan kelas, namun hal itu peneliti tidak memberikan fokus yang berarti. Karena peneliti merasa bahwa hal yang serupa demikian tidak mungkin terjadi dengan maksimal dalam waktu satu minggu tetapi hal yang dilakukan secara berulang-ulang.

Table Data aktivitas siswa dalam PBM siklus II

\begin{tabular}{|c|l|c|c|}
\hline No & \multicolumn{1}{|c|}{ Aspek yang dinilai } & Jumlah siswa Aktif & Perentase (\%) \\
\hline 1 & Memperhatikan penjelasan Guru & 29 & $100 \%$ \\
\hline 2 & Menjawab pertanyaan guru & 23 & $79 \%$ \\
\hline 3 & Memperbaiki jawaban yang salah & 29 & $100 \%$ \\
\hline 4 & Ikut menulis materi pelajaran & 29 & $100 \%$ \\
\hline 5 & Ikut membaca materi pelajaran & 29 & $100 \%$ \\
\hline \multicolumn{2}{|c|}{ Rata-rata aktivitas siswa (\%) } & $\mathbf{9 7 \%}$ \\
\hline
\end{tabular}

Data hasil observasi terhadap aktivitas siswa terjadi peningkatan $65 \%$ pada kegiatan prasiklus menjadi $88 \%$ di siklus I dan $97 \%$ pada silkus II, Kenaikan persentase aktivitas siswa disebabkan adanya tindakan guru yang terus membimbing siswa secara individu ikut mempengaruhi kenaikan aktivitas tersebut. Selanjutnya hasil observasi yang dilakukan guru terhadap PBM yang dilakukan oleh guru juga terjadi peningkatan karena dapat memperbaiki kekurangan dalam kegiatan prasiklus. Observasi juga dilakukan oleh guru yang sama di siklus I, dan siklus II untuk lebih jelas dapat dilihat pada table dibawah ini :

Tabel Data kemampuan PBM guru siklus II

\begin{tabular}{|c|c|c|}
\hline No & Aspek yang diamati & Katagori \\
\hline 1 & Guru menyampaikan tujuan pembelajaran & Amat.Baik \\
\hline 2 & Guru memotivasi siswa untuk mengikuti pelajaran dengan baik & Amat.Baik \\
\hline 3 & Guru mengelola PBM dengan menggunakan media belajar & Baik \\
\hline 4 & Guru membimbing siswa menulis secara individu & Amat.Baik \\
\hline 5 & Guru membimbing siswa membaca dengan benar & Baik \\
\hline 6 & Guru memberikan penjelasan akhir dan penguatan & Amat.Baik \\
\hline 7 & Guru melakukan penilaian & Baik \\
\hline \multicolumn{2}{|r|}{ Rata-rata Katagori } & Amat Baik \\
\hline \multicolumn{3}{|c|}{$\begin{array}{l}\text { Catatan : Dari data yang diperoleh rata-rata, kemampuan guru dalam melakukam } \\
\text { PBM adalah termasuk dari katagori Amat Baik, ini disebabkan karena telah } \\
\text { dilakukan perbaikan terhadap proses PBM pada siklus II. }\end{array}$} \\
\hline
\end{tabular}

\section{d. Refleksi}

Sebagaimana yang dilakukan pada kegiatan prasiklus, pada siklus I dan pada siklus II telah dilakukan penjelasan yang mendalam disertai media pembelajaran yang sesuai dengan metode studi pustaka terhadap deskripsi data yang dipaparkan diatas.

\section{e. Evaluasi}

Untuk mengetahui keberhasilan siswa secara klasikal pada akhir pembelajaran berlangsung di berikan tes akhir sebanyak sepuluh soal. 


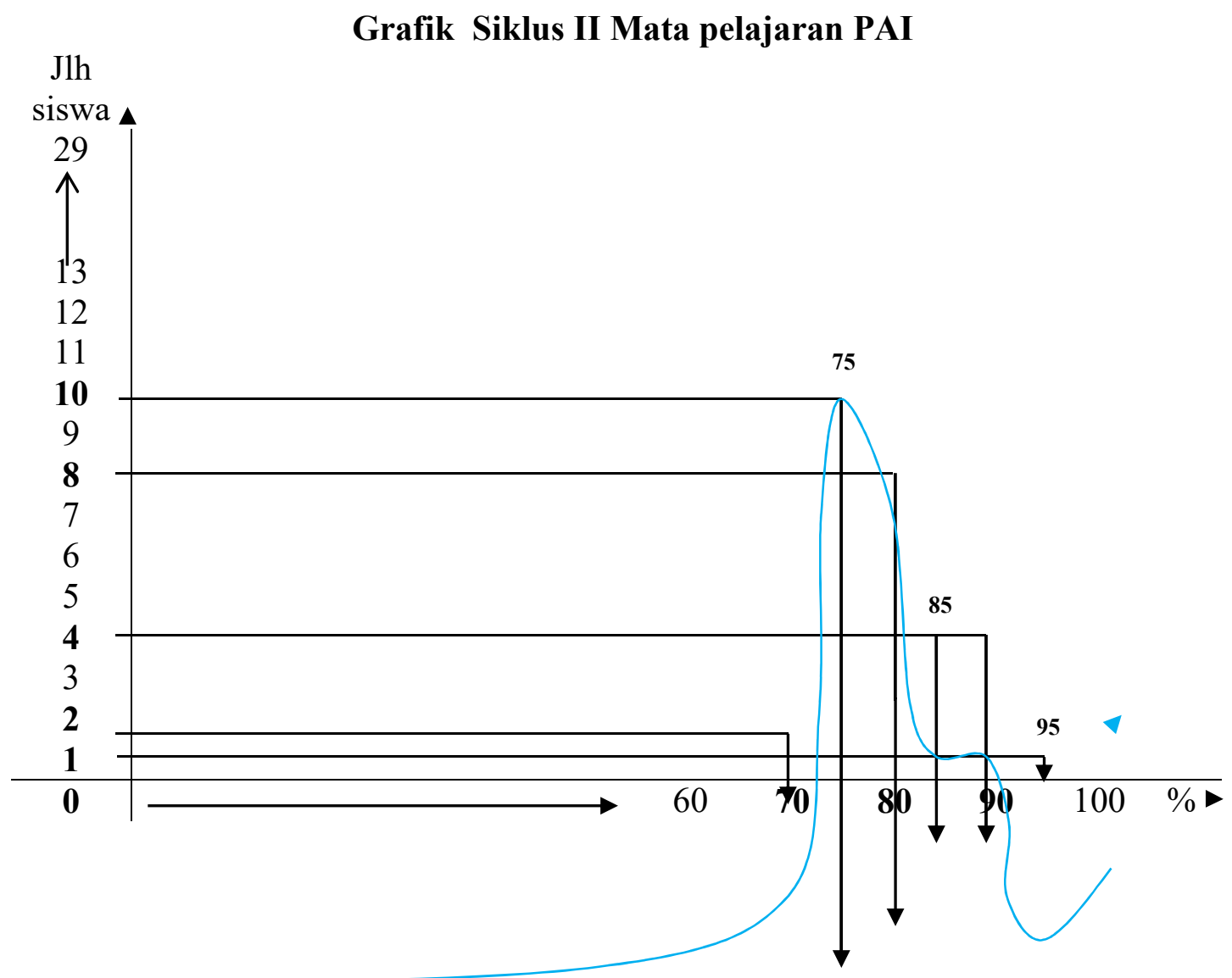

\section{Pembahasan Tiap Siklus dan Antar Siklus}

Berdasarkan hasil yang diperoleh dari pelaksanaan siklus, I, dan II maka dapat dikatakan bahwa terjadi peningkatan hasil belajar siswa pada pembahasan dalam menyupayakan peningkatan siswa dalam materi Iman Kepada Allah swt. dan al-asma al-husna dengan menggunakan metode studi pustaka.

Hasil belajar siswa yang diperoleh pada siklus I belum sesuai dengan yang di harapkan atau yang di inginkan $70 \%$. Hasil belajar prasiklus hanya 45\% siswa tuntas sebanyak 13 orang, sedangkan yang lain masih dibawah nilai KKM yang diharapkan. Mendapatkan hasil belajar yang belum sesuai dengan harapan yang di inginkan, maka dilanjutkan dengan siklus I dan siklus II guna untuk memperbaiki dan menyempurnakan aspek yang masih kurang maksimal pada kegiatan prasiklus. Setelah dilakukan siklus I dan II, ternyata terjadi peningkatan jumlah siswa yang memperoleh nilai lebih dari KKM seperti di siklus I sudah mendapat nilai 93\%, ini tentu nilai yang diharapkan, bahkan nilai tersebut hampir mencapai $100 \%$ di siklus II dari jumlah siswa 29 orang, jumlah persentase ini jelas menunjukkan bahwa telah terjadi perubahan besar dalam proses pembelajaran di siklus I dan II dengan katagori nilai amat baik.

Tabel Berikut ini data hasil belajar siswa per siklus

\begin{tabular}{|l|c|c|c|c|}
\hline \multirow{2}{*}{ Kegiatan } & \multicolumn{2}{|c|}{ Peroleh hasil belajar (KKM 70) } & \multicolumn{2}{c|}{ Ketuntasan (\%) } \\
\cline { 2 - 5 } & Nilai 70 ke Atas & Nilai 70 ke Bawah & Tuntas & Tak Tuntas \\
\hline Prasiklus & 16 Orang & 13 Orang & $55 \%$ & $45 \%$ \\
\hline Siklus I & 27 Orang & 2 Orang & $93 \%$ & $7 \%$ \\
\hline Siklus II & 29 Orang & 0 Orang & $100 \%$ & $0 \%$ \\
\hline
\end{tabular}


Observasi yang dilakukan terdapat aktivitas siswa pada kegiatan prasiklus sebanyak 65\% siswa aktif dalam kegiatan PBM, angka persentase keaktifan siswa belum maksimal, karena masih ada siswa yang belum dapat membaca dan menulis dengan benar. Hal ini disebabkan karena kurangnya bimbingan guru pendekatan secara individu kepada siswa, namun setelah dilakukan perbaikan dalam PBM pada siklus II terjadi peningkatan menjadi $88 \%$. dan pada siklus II menjadi $97 \%$.

Tabel Data aktivitas siswa antar siklus

\begin{tabular}{|c|c|c|c|c|c|c|c|}
\hline \multirow[b]{2}{*}{ No } & \multirow[b]{2}{*}{ Aspek yang diamati } & \multicolumn{2}{|c|}{ Prasiklus } & \multicolumn{2}{|c|}{ Siklus I } & \multicolumn{2}{|c|}{ Siklus II } \\
\hline & & $\begin{array}{c}\text { Jlh } \\
\text { Siswa } \\
\text { aktif }\end{array}$ & $\%$ & $\begin{array}{c}\text { Jlh } \\
\text { Siswa } \\
\text { aktif }\end{array}$ & $\%$ & $\begin{array}{c}\text { Jlh } \\
\text { Siswa } \\
\text { aktif }\end{array}$ & $\%$ \\
\hline 1 & $\begin{array}{l}\text { Memperhatikan } \\
\text { penjelasan guru }\end{array}$ & 17 & $59 \%$ & 25 & $86 \%$ & 29 & $100 \%$ \\
\hline 2 & $\begin{array}{l}\text { Menjawab pertanyaan } \\
\text { guru }\end{array}$ & 9 & $31 \%$ & 19 & $65 \%$ & 23 & $79 \%$ \\
\hline 3 & $\begin{array}{l}\text { Memperbaiki jawaban } \\
\text { yang salah }\end{array}$ & 22 & $76 \%$ & 26 & $90 \%$ & 29 & $100 \%$ \\
\hline 4 & $\begin{array}{l}\text { Ikut menulis materi } \\
\text { pelajaran }\end{array}$ & 22 & $76 \%$ & 29 & $100 \%$ & 29 & $100 \%$ \\
\hline 5 & $\begin{array}{l}\text { Ikut membaca materi } \\
\text { pelajaran }\end{array}$ & 24 & $83 \%$ & 29 & $100 \%$ & 29 & $100 \%$ \\
\hline \multicolumn{2}{|c|}{ Rata-rata siswa aktif (\%) } & & $65 \%$ & & $88 \%$ & & $97 \%$ \\
\hline
\end{tabular}

Persentase kemampuan guru dalam melaksanakan PBM pada prasiklus juga terjadi peningkatan kemampuan guru dalam mengolah PBM dengan katagori cukup dan pada siklus I dengan katagori baik serta pada siklus II dengan katagori amat baik. Maka menandakan bahwa peningkatan ini terjadi karena perbaikan tindakan yang dilakukan pada siklus I dan siklus II terhadap kekurangan PBM yang dilaksanakan pada kegiatan prasiklus. Data kemampuan guru pada saat melaksanakan PBM antar siklus dapat dilihat pada table dibawah ini.

Tabel Data kemampuan PBM guru antar siklus

\begin{tabular}{|c|c|c|c|c|}
\hline \multirow{2}{*}{ No } & \multirow{2}{*}{ Aspek yang diamati } & \multicolumn{3}{|c|}{ Katagori/Siklus } \\
\hline & & Prasiklus & I & II \\
\hline 1 & $\begin{array}{l}\text { Guru menyampaikan tujuan } \\
\text { pembelajaran }\end{array}$ & Cukup & Baik & Amat Baik \\
\hline 2 & $\begin{array}{lcc}\text { Guru memotivasi } & \text { siswa } & \text { untuk } \\
\text { mengikuti pelajaran dengan baik } & \end{array}$ & Cukup & Cukup & Amat Baik \\
\hline 3 & $\begin{array}{l}\text { Guru mengelola } \quad \text { PBM } \\
\text { menggunakan media belajar }\end{array}$ & Kurang & Baik & Baik \\
\hline 4 & $\begin{array}{l}\text { Guru membimbing siswa menulis } \\
\text { secara individu }\end{array}$ & Cukup & Baik & Amat Baik \\
\hline 5 & $\begin{array}{l}\text { Guru membimbing siswa membaca } \\
\text { dengan benar }\end{array}$ & Cukup & Baik & Baik \\
\hline 6 & $\begin{array}{l}\text { Guru memberikan penjelasan akhir dan } \\
\text { penguatan }\end{array}$ & Cukup & Baik & Amat Baik \\
\hline 7 & Guru melakukan penilaian & Baik & Baik & Baik \\
\hline & Rata-rata Katagori & Cukup & Baik & Amat Baik \\
\hline
\end{tabular}


Berdasarkan dari seluruh hasil tindakan yang menunjukkan terjadi peningkatan hasil belajar siswa, peningkatan kreatif siswa serta meningkatkan terhadap kemampuan dalam melaksanakan proses belajar mengajar, maka dapat disimpulkan bahwa gambar merupakan sebagai media pembelajaran yang digunakan pada materi Iman Kepada Allah swt. dan al-asma al-husna dalam pelajaran Pendidikan Agama Islam khusus untuk kelas VII SMP Negeri 2 Sampoiniet.

\section{Kesimpulan}

Dari hasil kegiatan pembelajaran yang telah dilakukan selama tiga siklus, dan berdasarkan seluruh pembahasan serta analisis yang telah dilakukan dapat disimpulkan yaitu pembelajaran dengan berbasis masalah memiliki dampak positif dalam meningkatkan prestasi belajar siswa yang ditandai dengan peningkatan ketuntasan belajar siswa dalam setiap siklus, yaitu pada kegiatan prasiklus (45\%), siklus I (93\%), siklus II (100\%). Penerapan metode pemberian tugas belajar dan resitasi mempunyai pengaruh positif, yaitu dapat meningkatkan motivasi belajar siswa yang ditunjukan dengan hasil wawancara dengan sebagian siswa, rata-rata jawaban siswa menyatakan bahwa siswa tertarik dan berminat dengan metode studi pustaka dan resitasi sehingga mereka menjadi termotivasi untuk belajar.

\section{DAFTAR PUSTAKA}

Arikunto, Suharsimi. 1997. Dasar-dasar Evaluasi Pendidikan. Jakarta: Bumi Aksara. Berg, Euwe Vd. (1991). Miskonsepsi agama islam dan Remidi Salatiga: Universitas Kristen Satya Wacana.

Hamalik, Oemar. 2002. Psikologi Belajar dan Mengajar. Bandung: Sinar Baru Algesindo.

Joyce, Bruce dan Weil, Marsh. 1972. Models of Teaching Model. Boston: A Liyn dan Bacon.

Masriyah. 1999. Analisis Butir Tes. Surabaya: Universitas Press.

Mukhlis, Abdul. (Ed). 2000. Penelitian Tindakan Kelas. Makalah Panitia Pelatihan Penulisan Karya Ilmiah untuk Guru-guru se-Kabupaten Tuban.

Nur, Moh. 2001. Pemotivasian Siswa untuk Belajar. Surabaya. University Press. Universitas Negeri Surabaya.

Soedjadi, dkk. 2000. Pedoman Penulisan dan Ujian Skripsi. Surabaya; Unesa Universitas Press.

Suryosubroto, B. 1997. Proses Belajar Mengajar di Sekolah. Jakarta: PT. Rineksa Cipta.

Usman, Uzer. 2000. Menjadi Guru Profesional. Bandung: PT. Remaja RoSMPakarya. Widoko. 2002. Metode Pembelajaran Konsep. Surabaya: Universitas Negeri Surabaya. 